\title{
THE RELATIONSHIP OF FAMILY ROLES AND ATTITUDES IN CHILD CARE WITH CASES OF CAPUT SUCCEDENEUM IN RSUD LABUANG BAJI, MAKASSAR CITY IN 2018
}

\author{
Oleh \\ Herman \\ STIKES Yapika Makassar \\ Email : $\underline{\text { hermanmm68@gmail.com }}$
}

\begin{abstract}
Newborns (BBL) are babies who have just undergone the birth process, aged 0-28 days. BBL requires physiological adjustments in the form of maturation, adaptation (adjusting from intrauterine life to extraurine life) and tolerating BBL to live well. The succedeneum head is a banjolan or swelling due to the presence of lymph nodes in the head (at the percentage of the head) that occur in babies born. The purpose of this study was to determine the relationship of family roles and attitudes in the care of children with cases of headache succedeneum. The method used was cross sectional, using the chi square test design. The sample of 34 respondents was chosen by using purposive sampling at RSUD Labuang Baji Makassar. The results of this study showed that respondents with positive succedeneum caput were as many as $88.2 \%$ of respondents who played a role and fewer than negative respondents who played no role namely as much as $11.8 \%$. Based on the chi square test, the analysis shows the relationship between family attitudes in child care and the succedeneum caput results obtained by analysis of indigo $p=0.005<\alpha=0.005$. The conclusion is there is a relationship between the role and attitudes of families with child care cases of succedeneum caput.
\end{abstract}

\section{Keywords: Bbl, Role, Attitude \& Caput Succedeneum}

\section{PENDAHULUAN}

Bayi baru lahir (BBL) adalah bayi yang baru mengalami proses kelahiran, berusia 0-28 hari. BBL memerlukan penyesuain fisiologi berupa maturasi, adaptasi (menyusuaikan diri dari kehidupan intrauteri ke kehidupan ekstraurine) dan tolerasi BBL untuk dapat hidup dengan baik.

Bayi baru lahir disebut juga dengan neonatus merupakan individu yang sedang bertumbuh dan baru saja mengalami trauma kelahiran serta harus dapat melakukan penyesuaian diri dari kehidupan intrauterine ke kehidupan ekstrauterin.

Caput succedeneum merupakan penumpukan cairan serosanguineous, subkutan dan ekstraperiosteal dengan batas yang tidak jelas.Kelainan ini biasanya pada presentasi kepala, sesuai dengan posisi bagian mana yang bersangkutan.Pada bagian tersebut terjadi edema sebagai akibat pengeluaran serum dari pembuluh darah.Kelainan ini disebabkan oleh tekana bagian terbawah janin saat melawan dilatasi serviks.Caput succedeneum menyebar melewati garis tengah dan sutura serta berhubungan dengan moulding tulang kepala. Caput succedeneum biasanya tidak menimbulkan komplikasi dan akan menghilang beberapa hari setelah kelahiran. Terapi hanya berupa observasi

Menurut Word Health Organization (WHO), pada tahun 2013 Angka Kematian Bayi (AKB) di dunia 34 per 1.000 kelahiran hidup, AKB Negara berkembang 37 per 1.000 kelahiran hidup dan AKB di Negara maju 5 per 1.000 kelahiran hidup. AKB di Asia Tenggara 24 per 1.000 kelahiran hidup dan Asia Barat 21 per 1.000 kelahiran hidup.Pada tahun 2013 AKB di Indonesia mencapai 25 per 1.000 kelahiran hidup.bila dibandingkan dengan Malaysia. Filipina dan Singapura, angka tersebut lebih besar dibandingkan dengan 
angka dari Negara-negara tersebut dimana AKB Malaysia hidup

Berdasarkan data Sulawesi Selatan yang diperoleh dari profil dinas kesehatan pada tahun 2015 jumlah kematian bayi menjadi 1.056 bayi atau 7.23 per 1000 kelahiran hidup yang disebakan oelh beberapa faktor seperti pertumbuhan janin yang lambat, kekuranga gizi pada janin, kelahiran premature dan berta badan lair rendah (BBLR) sedangkan penyebab lainnya yang cukup banyak terjadi adalah kejadian kurangnya oksigen dalam rahim (hipoksia intrauterus) dan kegagalan nafas secara spontan dan teratur pada saat lahir atau beberapa saat setelah lahir (afiksia lahir), dan trauma persalinan (chefalhematoma, caput succedaneum), maka masih perlu peran dari semua pihak yang terkait dalam rangka penurunan angka tersebut sehingga target Milinium Development Goals (MDGs) khususnya penurunan angka kematian dapat tercapai.

Pengambilan data awal yang dilakukan di Rumah Sakit Umum Daerah Labuang Baji Makassar didapatkan jumlah kasus bayi baru lahir dengan caput succedeneum pada tahun 2016 sebanyak 278 bayi, pada tahun 2017 sebanyak 275 bayi, sedangkan pada tahun 2018 sebanyak 135 bayi.(Ruangan Rekam Medik, RSUD Labuang Baji Makassar, 2018).

\section{METODE PENELITIAN}

Penelitian ini merupakan jenis penelitian analitik untuk mengetahui hubungan peran dan sikap keluarga dalam perawatan anak dengan kasus caput succedeneum dengan menggunakan pendekatan Cross sectional yang merupakan rancangan penelitian dengan melalukan pengukuran atau pengamatan pada saat bersamaan (sekali waktu) antara faktor risiko/paparan dengan penyakit.

Variabel terikat pada penelitian ini adalah bayi baru lahir dengan kasus caput succedeneum dan variable bebas adalah peran keluarga dan sikap keluarga.

Data ini diperoleh kuesioner. Data primer adalah data yang langsung memberikan data pada pengumpul data. Dalam penelitian ini hasilnya dapat diperoleh dengan cara melakukan wawancara, observasi, kuesioner yang telah di isi langsung oleh responden. sedangkan Data sekunder adalah sumber yang tidak langsung memberikan data kepada pengumpul data, misalnya orang lain atau lewat dokumen. Analisis data penelitian ini menggunakan analisis univariat dan bivariate dengan uji chi square.

\section{HASIL DAN PEMBAHASAN}

Berdasarkan hasil penelitian yang dilakukan di RSUD labuang baji Makassar mengenai hubungan peran dan sikap keluarga dalam perawatan anak dengan kasus caput succedeneum, dapat dilihat ditabel berikut.

Tabel 1. Distribusi responden berdasarkan peran keluarga dalam perawatan anak dengan kasus caput succedeneum

\begin{tabular}{|c|c|c|c|c|c|c|c|}
\hline \multirow{3}{*}{$\begin{array}{c}\text { Peran } \\
\text { keluarga }\end{array}$} & \multicolumn{4}{|c|}{ Caput Succedeneum } & \multicolumn{2}{|c|}{ Total } & \multirow{3}{*}{$\begin{array}{c}P \\
\text { value }\end{array}$} \\
\hline & \multicolumn{2}{|c|}{ Positif } & \multicolumn{2}{|c|}{ Negatif } & & & \\
\hline & $\mathrm{n}$ & $\%$ & $\mathrm{n}$ & $\%$ & $\mathrm{n}$ & $\%$ & \\
\hline Ya & 26 & 92,2 & 2 & 7,1 & 28 & 100,0 & \\
\hline Tidak & 4 & 66,7 & 2 & 33,3 & 6 & 100,0 & \\
\hline Total & 30 & 88,2 & 4 & 11,8 & 34 & 100,0 & \\
\hline
\end{tabular}

menunjukkan bahwa dari responden yang memiliki peran keluarga ya, dan caput succedeneum yang positif sebanyak $26(92,2 \%)$ orang, sedangkan yang memiliki peran keluarga ya tetapi caput succedeneum yang negatif sebanyak $2(7,1 \%)$, sedangkan pada kelompok responden yang memili peran keluarga tidak, dan caput succedeneum yang positif sebanyak $4(66,7 \%)$ orang, sedangkan yang memiliki peran keluarga tidak tetapi caput succedenum yang negatif sebanyak $2(33,3 \%)$ orang.

Analisis menunjukkan hubungan antara peran keluarga dengan dalam perawatan anak 
dengan kasus caput succedeneum, diperoleh hasil dengan analisis Uji Chi Square diperoleh nilai $\mathrm{P}=0,003<\alpha=0,003$ yang berarti bahwa ada hubungan antara peran keluarga dengan perawatan anak dengan kasus caput succedeneum.

Tabel 2. Distribusi responden berdasarkan sikap keluarga dalam perawatan anak dengan kasus caput succedeneum.

\begin{tabular}{|c|c|c|c|c|c|c|c|}
\hline \multirow{3}{*}{$\begin{array}{c}\text { Sikap } \\
\text { keluarga }\end{array}$} & \multicolumn{4}{|c|}{ Caput succedeneum } & \multicolumn{2}{|c|}{ Total } & \multirow{2}{*}{$\begin{array}{c}\mathbf{P} \\
\text { value }\end{array}$} \\
\hline & \multicolumn{2}{|c|}{ Positif } & \multicolumn{2}{|c|}{ Negatif } & & & \\
\hline & $\mathrm{n}$ & $\%$ & $\mathrm{n}$ & $\%$ & $\mathrm{n}$ & $\%$ & 0,005 \\
\hline Ya & 28 & 87,5 & 4 & 12,5 & 32 & 100,0 & \\
\hline Tidak & 2 & 100,0 & 0 & 0,0 & 2 & 100,0 & \\
\hline Total & 30 & 88,2 & 4 & 11,8 & 34 & 100,0 & \\
\hline
\end{tabular}

menunjukkan bahwa dari responden yang memiliki sikap keluarga ya, dan caput succedeneum yang positif sebanyak $28(87,5 \%)$ orang, sedangkan yang memiliki sikap keluarga ya tetapi caput succedeneum yang negatif sebanyak 4 (12,5\%), sedangkan pada kelompok responden yang memili sikap keluarga tidak, dan caput succedeneum yang positif sebanyak $2(100,0 \%)$ orang, sedangkan yang memiliki sikap keluarga tidak tetapi caput succedenum yang negatif sebanyak $0(0,0 \%)$ orang.

Analisis menunjukkan hubungan antara sikap keluarga dengan dalam perawatan anak dengan kasus caput succedeneum, diperoleh hasil dengan analisis Uji Chi Square diperoleh nilai $\mathrm{P}=0,005<\alpha=0,005$ yang berarti bahwa ada hubungan antara sikap keluarga dengan perawatan anak dengan kasus caput succedeneum.

Hubungan peran keluarga dalam perawatan anak dengan kasus caput succedeneum

Keluarga adalah salah satu kelompok atau kumpulan manusia yang hidup bersama sebagai satu kesatuan atau unit masyarakat terkecil dan biasanya selalu ada hubungan darah, ikatan perkawinan atau ikatan lainnya, tinggal bersama dalam satu rumah yang dipimpin oleh seorang kepala keluarga dan makan dalam satu periuk

Hasil penelitian menunjukkan bahwa pada responden dengan caput succedeneum yang positif lebih banyak pada responden yang berperan ya yaitu sebesar $88,2 \%$ dan lebih sedikit dari responden negatif yang berperan tidak yaitu sebanyak 11,8\%.

Hubungan sikap keluarga dalam perawatan anak dengan kasus caput succedeneum

Menurut (Wawan A, dan Dewi M.2010). Menjelaskan sikap dapat diposisikan sebagai hasil evaluasi terhadap objek sikap yang diekspresikan terhadap proses-proses komunitif, efektif(emosi), dan perilaku

Menurut hasil penelitian dapat dilihat bahwa pada responden dengan caput succedeneum yang positif lebih banyak pada responden yang berperan ya yaitu sebanyak $88,2 \%$, sedangkan responden dengan caput succedeenum negatif yang berperan tidak yaitu sebanyak $11,8 \%$.

\section{PENUTUP}

\section{Kesimpulan}

1. Ada hubungan antara peran keluarga dengan perawatan anak kasus caput succedeneum.

2. Ada hubungan antara sikap keluarga dengan perawatan anak kasus caput succedeneum

\section{Saran}

1. Untuk institusi.

Sebagai bahan kajian, masukan dan dasar pemikiran bagi mahasiswa khususnya untuk penelitian lebih lanjut, guna meningkatkan kualitas pendidikan

2. Untuk peneliti

Penelitian ini merupakan pengalaman berharga, diharapakan dapat lebih memperluas wawasan dan pengetahuan peneliti dan sebagai sumbangan yang diharapkan dapat 
bermanfaat untuk pembaca dan peneiliti berikutnya

\section{DAFTAR PUSTAKA}

[1] Arief Zr Dan Sari, 2014, Neonatus Dan Asuhan Keperawatan Anak Yogyakarta: Nuha Medika

[2] Angka Kematian Bayi (AKB) di Indonesia Menurut WHO, (http://repository.usu.ac.id/bitstream/handl e/123456789/50561/Chapter\%20I.pdf?seq uence $=5$.)

[3] Asuhan Kebidanan Neonatus Caput Succedeneum (https://www.ejournal.stikesmucis.ac.id/F assets/dokumen/13DB277053.pdf)

[4] Azwar S, 2013, Sikap Manusia: Teori Dan Pengukuran, Jakarta: Pustaka Pelajar

[5] Departemen Pendidikan dan Kebudayaan RI (1975).Pedoman Umum Ejaan Bahasa Indonesia yang Disempurnakan.Jakarta:Balai Pustaka

[6] Dewi, Vivian Nanny Lia.2013, Asuhan Neonatus Bayi Dan Anak Balita, Jakarta: Salemba Medika.

[7] Diouf dkk : / Jurnal Of Neonatal and Pediatric Medicine. Vol. 3. Issue. 1, Maret 2017.

[8] Jenny J.S. Sondakh.2014.Asuhan Kebidanan Persalinan \& Bayi Baru Lahir,Jakarta:Erlangga, 7

[9] Laili Jamilatus Sanifa, 2018, Hubungan tingkat pengetahuan dengan sikap keluarga

[10]Lockhart Rn Dan Dan Lyndon Saputra,2014, Asuhan Kebidanan Neonatus Normal Patologis, Tanggerang Selatan: Binarupa Aksara Publisher

[11]Manggiasih, Vidia Atika \& Pongki jaya.2016.Asuhan Kebidanan Pada Neonatus, Bayi,Balita Dan Anak Pra Sekolah, Jakarta Timur, DKI Jakarta: Cv Trans Info Media.

[12] Marni dan Kukuh Rahardjo.2015.Asuhan Neonatus, Bayi, Balita Dan Anak Pra Sekolah, Yogyakarta: Pustaka Pelajar
[13] Manajemen Asuhan Kebidanan,Caput Succedeneum,2014 (https://repositori.uin alauddin.ac.id/2F5551212.pdf)

[14]Maryunani, Anik dan Eka Puspita Sari.2014. Asuhan Kegawatdaruratan Maternal \&Neonatal, Jakarta: Cv Trans 